she began to amend, and ultimately recovered from such a condition as one had learned by sad experience to regard as quite a hopeless one. Several times in 24 hours she received a subcutaneous injection of some ounces of normal saline fluid to which were added small doses of strychninefor her heart's action was of the feeblest-and in and through these means she exists to-day.

Here, then, may end my quest. Early operation in appendicitis (that is, within the first 48 hours) I practise only in the grave cases and I am happily able to bear strong testimony to its value and its success, for I have never found it increase a peritonitis already in existence-indeed, it has cured it. The difficulty has often been the prompt recognition of those conditions in which delay too often spells deaths, and my endeavour has been to render, if possible, their recognition more facile and less hesitating.

Cannes, France.

\section{THE HISTORY OF THE DISCOVERY OF TRYPANOSOMES IN MAN.}

BY RUBERT W. BOYCE, M.B. LOND., F.R.S., HOLT PROFESSOR OF PATHOLOGY IN UNIVERSITY COLLEGE, LIVERPOOL;

RONALD ROSS, C.B., F.R.C.S. ENG., F.R.S.

MAJOR, I.M.S. (RETIRED), PROFESSOR OF TROPICAL MEDICINE IN UNIVERSITY COLLEGE, LIVERPOOL

AND

CHARLES S. SHERRINGTON, M.A., M.D. Cantab., F.R.S.,

HOLT PROFESSOR OF PHYSIOLOGY IN UNIVERSITY COLLEGE, LIVERPOOL.

MISTAKES as to priority in scientific discoveries are so frequently made, are so easily perpetuated, and are so discouraging to workers that we shall present no apology for attempting a critical history of the discovery of trypanosomes as parasites in man. There is the more call for someone to undertake this task because the discovery promises to be an important one and because some fragmentary dis. cussion regarding it has already taken place. So far as we know at present there are five possible claimants in the field-namely, Hehir, Barron, Nepveu, Forde, and Dutton. We propose to examine their respective claims as thoroughly as possible, but must premise that we can judge of these claims only by means of the published documents which are now before us and which we mention specifically in the footnote references.

Major Patrick Hehir, I.M.S. (1891, 1892).--So far as we know no claim has yet been advanced in favour of this observer being the discoverer of the human trypanosome, but as this claim may be made in the future and as his case appears to be as good as those of the two following observers, we may as well deal with it here. The first mention made by Major Hehir of anything like a trypanosome is contained in his work on Malaria (1891), p. 14, ${ }^{1}$ where he states that he met with " trichomonas-like" bodies in six out of bis 343 cases and "pyriform" bodies in 39 cases. Of the first form he says : "It remains transparent and structureless throughout, but acquires two or more filamentary processes after leaving the corpuscles. Originally I thought that these were distinct structures and in no way related to the other forms" (i.e., Laveran's bodies). "It may be found in the blood cells or free. In the latter case it soon acquires two flagellae (sio), one at each extremity, and sometimes throws out small flagellae from its irregular border." This last clause suggests the undulatory membrane of trypanosomes and monads. Of the pyriform body he says that it possesses "a single active flagella" and that "it varies considerably in size ; it is structureless, and remains so, except that after some time mobile pigment granules are seen in it. After a few hours from this period it is set free $;. . .$. it appears to be a misshapen crescent." In thinking that bis flagellate bodies issue from the red corpuscles, Major Hehir evidently had the hæmogregarines in mind; but he seems to have dropped this idea in his next publication. The presence of pigment in the pyriform body suggests that it was a malarial gametocyte. The work is illustrated with rough drawings in outlice, and those of the trichomonas-like and

1 Hehir: Microscopical Observations on the Hæmatozoon of Malaria, 1891. Madras : Lawrence Asylum Press. pyriform bodies (Plate IV., Figs. 3 and 4) may just possibly be meant for trypanosomes. Next year (1892) Major Hehir published a long paper on parasites found in the "blood and excreta in cases of cholera," 2 and on page 3 mentions finaing "trichomonas-like bodies with a wavy border on one side and long tapering flagellæ arising from the extremities." This description might certainly suggest monads as much as trypanosomes; but, on the other hand, some of the drawings of these objects (Plate V., Fig. 3) are distinctly like the latter, especially the one with a vacuole at one end and a flagellum at the other, which certainly seems to be meant to be a trypanosome. With regard to the nomenclature used by Major Hehir for his flagellate organisms (Trichomonas), we may remark that there was at one time considerable confusion between the parasite groups of trypanosomes and monads. ${ }^{3}$ Both groups have undulatory fringes, or at least lateral flagella, and the number of terminal flagella in the monad group was by no means quickly determined. Lewis ${ }^{4}$ at first thought that his trypanosome of rats belonged to the monad group and various names have been given to trypanosomes by various observers, as for instance, Hamatomonas (Mitrophanow) Herpetomonsa (Saville Kent), and Imchomonas (Crookshank, 1890). The last is the name used by Major Hehir in $189 \mathrm{~L}$ and 1892. Gruby's name Trypanosoma did not come into general use until later; and we cannot therefore object to Major Hehir that he did not use it in his papers under reference. Apart from this it may be argued that he must have been observing trypanosomes whatever his nomenclature was, because organisms of the monad group (e.g., Cercomonas Davaine or Trichomonas Donné) have not yet been demonstrated with certainty in the blood.

We certainly cannot say definitely that Major Hehir did not find trypanosomes in human blood; but, on the other hand, we should be sorry to admit definitely, on the published evidence, that he did find them. His frst paper referred to above ${ }^{5}$ describes and figures many objects which he considers to be parasites of malaria but which are more like artifacts and at all events are not admitted by any of the best authorities on malaria. In his paper on the organisms of cholera he gives 15 full-page plates of rough drawings of very sirgular objects which appear to be zoologically impossible. In 1895 Hankin ${ }^{6}$ expressed an opinicn that most of Major Hehir's cholera parasites were "nothing but crystals of common salt, ...... various kinds of precipitates, fragments of fibrin, altered red or white blood corpuscles, or even masses of bacteria. Next year Major Hehir ${ }^{7}$ published another long paper on malaria in which he claims to have found the spores of the malaria parasites in soil and water ; to have detected "free flagella" in syphilitic blood; and to have proved that "the Amoba coli is a true flagellated sporozoon." We would add, however that at one time Major Hehir was considered an authority and his paper on cholera was issued as a special supplement of the Indian Medical Gazette. Numerous other papers by him of a nature similar to: those we have quoted can be found in the pages of that journal from 1891 up to his reply to Hankin. ${ }^{9}$ Since 1897, however, we have seen no further contributions from his pen.

Dr. Alexander Barron (1894).-Dr. Laveran seems to bave been the first to draw attention by a brief note in his book "Traité du Paludisme" to a short communication made to the Liverpool Medical Institution by Dr. Barron, ${ }^{10}$ then professor of pathology at University College, Liverpool. We transcribe the entire passage as we find it. "December, 6th, 1894. - Dr. Barron related a case of a lady, aged 39, the

2 Hehir: Microscopical Observations on the Blood and Excreta in Cases of Cholera, Indian Medical Gazette, Spccial Supplement, April, 1892 p. 407 . 4 Quarterly Journal of Microscopical Science, vol. xix, (2), 1879, D. 109

(he Hicroscopical Observations on the Hazon of Malaria, 1891 Madras : Lawrence Asylum Press

Hankin: A Contribution to the Etiology of Cholera, Indian Medical Gazette, 1895 , p. 207

Hehir: The Hæmatozoon of Malaria and its Discovery in Water and Soil, THE LaNCET, Nov. 28th (p. 1514) and Dec. 5th (p. 1589), 1896. 8 See, for instance, the translator's preface to Laveran's Du Paludisme, New Sydenham Society, vol. cxlvi., 1893

9 Hehir: A Contribution to the Etiological Relations of Choler (reply to Hankin). Indian Medical Gazette, 1896, p. 264.

10 Barron: Untitled communication to the Liverpool MedicoChirurgical Journal, including the Proccedings of the Livcrpool Medical Institution, January, 1895, p. 232 
subject of a uterine fibroid, which had ceased to bleed after phlebitis and an attack of influenza, who, in the early part of this year, there being no hæmorrhage of any kind, began to become anæmic and had a peculiar earthy complexion, sugge-ting possible malignant disease. On examination in August no evidence of any organic disease beyond the fibroid could be found, but the blood contained large numbers of flagellated protozoa, as many as eight or ten in the field of the microscope $\frac{1}{12}$ oil immer-ion. She was not seen again until October, when she appeared to be, and said she was, perfectly well. No protozoa could be found. She was treated with arsenic, aloes, and iron. No change in diet or surroundings." The note ends here and the minutes of the Liverp ol Merical Institution give no additional details. On Jan. 16th, 1902, one of us formally asked the members of the institution whether any of them could throw further light on the subject. The only reply given was one by Professor H. Briggs, who stated that the case was his own and that "Dr. Barron's organism was, in his own opinion, not like Dr. Dutton's specimens." (We may explain that the phrase "Dr. Dutton's specimens" refers to some preparations of the human trypanosomes found by him and Mr. $\mathbf{R} M$. Forde in the Gambia some weeks previously, as will be presently described.) A short ab tract of these proceedings will be found in the British Medical Jurnal. ${ }^{11}$ Dr. Barron's case is the more tantalising because, being an expert pathologist, he was not likely to have been misled by artifacts. It will be noted, however, that the parasites were said to be flagellated protozoa; that they were very numerous ; that there are no statements regarding their size, form, structure, and zoological affinities, and no drawings of them; and that it is not mentioned whether the patient had ever been in the tropics. Professor Briggs's stat ement suggests that they were not trypanosomes; and in fact it remains impossible to ascertain what they were.

Dr. Gustav Nepveu (1898). - So far as we know this is the first observer who actually uses the name "trypanosome" for the flagellate organisms which he claims to have found in human blood. His paper ${ }^{12}$ has no illustrations and is only a page and a quarter in length; but the author states perfectly definitely in it that he had found trypanosomes in human blood. He begins by remarking that up to the present trypanosomes had been found only in certain animals; but be refers to Dr. Barron's case. He proceeds :

In 1890, in pursuance of (à la suite de) researches made in Algeria on the parasite of malaria $I$ found in the blood of a patient in whom Laverania also were present, conjointly with them, a flagellate oryanism which was common enough; I counted about three of them in each preparation of $18 \mathrm{~mm}$. square. About this time (see Nepveu: Etude sur les Parasites du Sang cbez les Paludiques, gave some of the drawings which I had collected up to that time. always hoped to be able to complete, by a more detailed stuily, these first observations; but since then I have found the parasite again only ou rare occasions. I therefore decided to give the few details which
follow in the hope of drawing the attention of naturalists and physicians, who will be able to complete these researches.

This trypanosome shows all the characters of the genus: genera form, a colourless homogeneous membrane, of which one of the borders, thinner and more hyaline than the other, is animated by the charac teristic undulatory movements. This membrane carries a nucleus and a fine fiagellum placed in front, the undulations of which follow each other rapinly.

It is thus that it appeared in Khill (quotidian fever) and in Cabane (pernicious comatose fever). In a third patient, Genestet, I observed organisms which I thought were related to those described under the name of "trypanomones," a form which is, perhaps, only a stage of evolution of trypanosomes. In this patient the organisms wer furnished with two flagella at one of

In more than 200 patients, for the most part malarial, of which I In more than $2 C 0$ patients, for the most part malarial, of which I
have studied the blood I have tound these various forms only in six. have sturlied the blood I have tound these various forms only in six.
Three of these were suffering from quotidian fever (Khill, Langevelde, Three of these were suffering from quotidian fever (Khill, Langevelde,
Bichielli), one from a tertian type of fever (Hendrick), two from perBichielli), one from a tertian type of fever (Hendrick), two from per was made on Ur. X-, who was apparently in good health (larval paludism)

paludism)

In none of these patients have I observed any symptoms corresponding to this special parasite invasion. They were almost all invaded by This seems to be, therefore, a pure and simple coincidence which I

think worthy of notice.

In conclusion, the trypanosome ought to be placed among the parasites of the blood of man. I cannot give with all the precision desirable a more complete description of this variet $y$, I therefore do not wish to give it a particular name. It would be better, to begin with, to estab-
lish the similarities and differences which I find between this parasite of man and the congeneric ones observed in animals, and to complete first our morpholrigical and evolutive study of it.

1. Brit. Merl. Jour., 1902, vol. i., p. 205

Rendus et Mrémoires de la Société de Biologie, 1899, p. 1172.

13 Bulletin de la Société Zoologique de France, 2, xyi., pp, 229-231, 1891. (Author's reference.)
This is all. At a cursory glance nothing could be more convincing than this paper; but those who have studied the discoveries of new parasites which are so frequently made (e.g., in epilepsy, goitre, cholera, syphilis, small.pox, \&c.) will perhaps wish to inquire further. In the first place, we note that Dr. Nepveu's description of his trypanosome is merely what may be called a generic description and not a specific one; that is, it would apply equally well to almost all the kinds of trypanosomes known. Anyone who has seen the familiar trypanosomes of animals, or has even read an account of them in the text-books, could have written such a description. He gives no measurements and no drawings; he does not inform us (a thing which he might easily have done) which of the many trypanosomes figured in the text. books, and differing in many particulars from each other, most resemble his: and the position of the nucleus, the staining reactions, and the details of movement are not noted. (In the original passage, "Un noyau et un flayelle mince placé en avant," the word placé, being singular, refers only to flagelle.) He does not (in spite of his concluding sentence) make any effort to differentiate his trypanosomes from those of animals. The excuse which he gives for this lack of detail-namely, that he has found the parasite only on rare occasions--is scarcely adequate. Since then the most exact drawings and descriptions have been given from a single case, and yet Dr. Nepreu was not able to give them with the material of six (if not seven) cases. Surely he might have retained some preparations from some of these cases from which photographs or drawings at least could have been made. The reader should note that he expressly denies that his parasites were pathogenetic. This does not accord with what has been found in connexion with the majority of cases recently reported.

It will be observed that in one place he states that in the case of Genestet he had found organisms furnished with two Hagella at one of their extremities, that these organi:ms appeared to be allied to those called trypanomonads, "a form which is perhaps only a stage of evolution of the trypanosome," and that "Labbé has described a trypanomone of this kind." It has been gravely contended in favour of Dr. Nepveu's claim that the trypanosome with two flagella is so characteristic an object that it is not likely to have been imagined by him. It is true that trypanosomes undergoing fission have two or more flagella but as will be seen on reference to the classical works of Rabinowitsch and Kempner, Laveran and Mesnil Bradford and Plimmer, these flagella are unfortunately seldom or never at one end. In fact, each derivative organism has its own flagellum, and the freshly formed flagella are seen at the sides of the parent organism. Dr. Nepveu's remark seems to weaken rather than to support his case, and suggests that he had found, or thought that he had found, some multiflagellate organism such as a monad. Still more unfortunate is his reference to Labbé. On looking at the work of Labbe mentioned we find that his organism certainly had two flagella, but that they are placed one at each end. And Labbé does not apply the name "trypanomones" only to this kind but to the whole genus, much less does he give the name to organisms with two flagella at one end, as Dr. Nepveu suggests. The idea that trypanomonads are an earlier stage of trypanosomes is based upon a confusion of Danilewski's which we shall mention again.

Near the beginning of his paper Dr. Nepveu says that his discovery was originally made "en 1890, à la suite de recherches faites en Algérie," and that about this time he had already published drawings in the publications of the Société de Biologie. On referring to this article of his ${ }^{14}$ we find no drawing which purports to be, or which even clearly denotes, a trypanosome; while the article concludes with the most definite statement that he had not found trypanosomes at all, "in spite of the greatest care." The only justification which appears to exist for his reference to this earlier paper of his is that he claimed in it to have found " numerous characters seeming to indicate the presence of them (the trypanosomes) or, at least, of hæmatozoa like them" (p. 50)-a very different matter. By a close study of this and of a succeeding paper of Dr. Nepveu we find, in fact, that he has discovered many other parasites besides trypanosomes. This paper of 1891 is headed "Par M. le Professeur G. Nepveu de Marseille."

14 Nepveu: Etude sur les Parasites du Sang chez les Palndiques, Comptes Rendus et Mémoires de la Société de Biologie, 1891, p. 39. 
He begins by setting forth that the researches described by him were made in Algeria in the summer of 1888 and in August, 1890 (the latter apparently being the researches during which, as he claims in his article of 1898, he discovered the human trypanosome). He then passes in review all the parasitic forms which he has observed in the blood of malaria patients, but insists only on the points which he believes to be new (recalling a similar statement by Major Hehir). These parasitic forms are certainly as novel as they are numerous. They consist of "alques inférieures et schizomycètes" and of "infusoires flageliés et sporozoaires." By the flagellate infusoria he means (p. 48) Iaveran's parasites which were then often thought to be of this nature. Of the former class he discovers "masses zoogléiques" floating in great numbers in the blood of almost all the pernicious cases and disappearing on recovery; a microbacillus; a "bactérien en biscuit" which occurs not only in the blood of cases of malaria but in their stools and in the water of pits reputed to be malarious; "bacterriens en flotteurs"; also an "algue véritable" which demonstrates its existence in the blood by developing in (apparently) sealed specimens ; also spirilla which are generally fixed to the red corpuscles-" they therefore recall the bodies described by Laveran under the name of spherical bodies with flagella" (sio) ; also a "streptocoque paludique"; also a "bactérie caréniforme" which is furnished at its two extremities with long lashes perpendicular to its axis and which suddenly transforms itself into a crescent; also a "bactérie érucante" which he says has a "vague resemblance to the caterpillar of our gardens" and which has "singularly perplexed" the author because it may either be "a distinct species or a phase of the coccidium paludicum (sic) or a schizomycete." A similar body was found in the portal vein. In connexion with the "infusoires flagelles" the author describes what he thinks are Laveran's parasites. He begins with the spores, of which he has been able to count 20 in a single cell of a "villosite intestinale." They remain quiet for a time, to the number of four, five, or six, attached to a single corpuscle, but later give evidence of their existence by producing "formidable accidents." He refers especially to those of the larger hæmamœbæ which take the form of a starfish. One finds this free in serum, "animated with movements so rapid that it was very difficult to seize its form in an exact manner." There are other " amiboüdes bien curieus" which have four branches but which appear to lose the fourth foot when seen in profile (sic). He also describes some very singular "corps vésiculeux." We note especially the "corps clavifor me" and the "corps en geurde." Three of the latter were found fixed on the same corpuscle and had the appearance of gorged leeches or even of Cysticercus cellulose. The author also describes finding in the milk of two nurses an organism with the form of retort. All these forms, including certain "vésicules à queue" and "vésicules en larmes bataviques," are, according to the author, "très probablement des formes de transition très voisines de celles du trypanosome." On p. 50 he says that he is convinced that they "rapprochent beaucoup de certaines grégarines, de certaines coccides," but that he is unable to determine exactly their phases and much less their species. Nevertheless, he thinks that they represent "le stade sphérique ou la période de segmentation du trypano some." Why so, he does not explain. The figures of these bodies (Figs. 3, 12, and 23) resemble nothing that we know of in connexion with trypanosomes, or, indeed, with anything elee. It is unnecessary to deal with his descriptions of Laveran's crescents and his so-called "Hlagellate bodies" except to note that the latter are "almost always fixed inside the red corpuscles," which is of course seldom, if ever, the case. He describes three kinds of crescents. Fig. 31 is like these bodies, but Fig. 16 distinctly represents fragments of red corpuscles. He finds free flagella very frequently (as Major Hehir does). Some of his corps flagellés are triangular with a flagellum at each angle (Figs. 17 and 18). One of these (Fig. 17) is the only one of the drawings which presents the smallest likeness to a trypanosome; but on reference to the text (p. 48, paragraphs 4, 9, and 10) it appears to be one of Laveran's flagellate bodies of the triangular pattern.

Lest it be pretended that Dr. Nepveu has here drawn a real trypanosome we may remark that Fig. 17 represents a long narrow body with two flagella, with knobs at their ends, issuing from one extremity, and (?) a third flagellum at the other extremity. Now the adult trypanosome is certainly long and narrow but has only one flagellum; while the fission forms certainly may have two or more flagella, but are broad and generally partially divided objects with the flagella issuing from the sides-quite different, in fact, from the figure. But the matter is finally decided by the presence of the little knobs at the end of the flagella in the illustration. Dr. Nepveu had evidently read of the enlargement often seen at the end of Laveran's socalled flagellum, and consequently gives such an enlargement to all his figures of flagellate bodies (Figs. 17 and 18) and refers to it in his text as une petite vésioule terminale. Now the flagellum of the trypanosome never possesses an enlargement of this kind. Hence he was clearly not drawing a trypanosome. His other flagellate bodies strongly remind us of some of Major Hehir's drawings and are probably blood plates with filaments of fibrin attached. It is impossible to know what he means by his corps vermiformes. One would suspect filariæ but for the illustration, which suggests nothing of the kind. The illustrations of this work consist of a page of drawings in outline, roughly scratched by the point of a pen. They are very similar to those of Major Hehir; and most of them probably represent exactly the same objects-namely, artifacts, blood plates, fibrin, vacuoles, and adventitious bodies.

As we have already mentioned, he says near the end of his work: "Je n'ai jamais pu trouver, malgré le plus grand soin, la trypanomonade ou le trypanosome de Danilewski, mais certainement des caractères assez nombreux semblent en indiquer cependant la présence, ou tout au moins la présence d'un hématozoaire très voisin." This passage speaks for itself. It has been suggested that by "le trypanosome de Danilerssi" Dr. Nepveu meant a particular species of try. panosome which he could not find; but this reading is impossible because Danilewski mentioned many kinds of trypanosomes found in many animals. Nepveu evidently meant that he could not find trypanomonads or trypanosomes such as Danilewski had described. (We may explain that the name Trypanomonas was at one time given by Danilewski to Lewis's trypanosome of the rat in order to distinguish it from the trypanosome of frcgs. He thought that the former is an immature form of the latter, ${ }^{15}$ or at least a young trypanosome, and Dr. Nepveu seems to have some confused remembrance of this erroneous hypothesis. We have already spoken of Labbé's use of the word Trypanomonas.) Reviewing this paper of Dr. Nepveu we see that he expressly denies in it having ever found trypanosomes in his researches of 1888 and 1890. He claims only to. have found "characters which indicate the presence" of trypanosomes, but he gives no evidence whatever that the objects he refers to have any connexion with trypanosomes, or, indeed, with any other parasite. In fact, the whole raper suggests that, with the exception perhaps of Laveran's crescents, he was not describing true parasitic organisms at all, but simply a series of artifacts.

A little later, in the same Comptes Rendus, Dr. Nepveu ${ }^{16}$ records the discovery of yet another couple of parasitesnamely, of flagellate bodies included in the leucocytes in cases of malarial fever and of certain polygonal organisms in the same. The illustrations of the former are unlike anything which would now be considered possible ; and the discovery has not been confirmed. It is interesting to note, however, that two of the cases in which these organis ms occurred (p. 700) have the same names as two of the cases (Genestet and Cabane) in which the author claimed seven years later to have found trypanosomes. ${ }^{17}$ They suffered also from the same disease, pernicious fever. The polygonal cells have not been studied except by the author.

After this year (1891) we find a series of short publications by the author in the Comptes Rendus de la Société de Bivlogie. We cannot refer to them here, but would advise the reader who is interested in this matter to look through them. The heading of most of them suggests that Dr. Nepveu was at Marseilles during this period.

We have thus given a brief review of such of Dr. Nepveu's writings as we are acquainted with; and we would advise the reader to study them for himself if he wishes to form an inderendent opinion regarding them. We would suggest, however, that he study them in conjunction with the writings of Major Hehir and a paper on artifacts in the blood written by one of us (Ross ${ }^{18}$ ).

15 See, for instance, Annales de l'Institut Pasteur. 1890, p. 759.

16 Nepveu : Corps Flagellés inclus dans les Cellules Blanches chez lesPaludiques, \&c., Comptes Rendus et Memoires de la Société de Biologie, 1891 , p. 699

1898, p. 1173 (not un Trypar

18 Ross : A List of Natural Appearances in the Blood which bave heen Mistaken for Forms of the Malaria Parasite, Indian Medical Gazette, 1894 , p. 441 . 
Of course, as with Major Hehir and Dr. Barron, we cannot definitely say that Dr. Nepreu did rot find trypanosomes in human blood. Although his paper of 1891 contradicts his statement of 1898 , that he discovered them in 1890 , yet it is possible that he saw them later. We have no means of judging. The paper of 1898 is so vaguely worded that it is impossible to ascertain from it when and where the observations were made-that is, if they were not all made in Algeria in or before 1890. Beyond this the cases are neither localised nor dated. Are we to suppose that all the cases were found in Algeria in 1890 or that some were found subsequently up to 1898 ? In the latter event, where were they found? Did Dr. Nepveu return to Algeria after 1890 or did he find the cases in Marseilles or elsewhere? Surely be ought to have given some exact information on these points. Surely, also, considering the large amount of material he possessed in his six or seven cases, and in view of the importance of the discovery which he claims, he ought not to have allowed seven years to elapse before publishing, he ought to have given much more precise details than he did give and he ought to have placed his discovery beyond cavil by demonstrating his organisms to persons capable of judging them. If he did so, where are the facts recorded ?

At the same time his various papers fail to convince us that the author possessed any really accurate knowledge even of the literature of trypanosomes, or indeed of malaria. Like the papers of Major Hehir, they suggest that the author was an enthusiastic but inexperienced observer who mistook everything seen under a strong lens for some kind of parasite. If we cannot assure ourselves that these observers did not find flagellate organisms in the blood we certainly cannot, in spite of their statements, feel convinced that they did. It is possible that their flagellate organisms were artifacts, such as many of their other organisms certainly seem to be. There is no good evidence that Major Hehir ever saw his trichomonaslike body and there is no more evidence that Dr. Nepveu ever saw his trypanosome than that he saw flagellate bodies within the leucocytes or numerous curiosities which he mentions as existing in malarial blood. Even if the reader decides to grant these observers the benefit of the doubt he will be forced to consider the difficult question as to which of the two deserves the priority. Certainly Hehir's drawing of 1892 (Plate V., Fig. 3) presents as good an idea of a trypanosome as Dr. Nepveu's very general description of 1898 , and was published six years earlier. For our own part, unless some fresh evidence can be produced in their favour, we shall be forced to conclude that the claims of Major Hehir, Dr. Barron, and Dr. Nepveu are all of them, to say the least, very questionable. Laveran and Mesnil have already independently come to the same conclusion regarding those of Dr. Barron and Dr. Nepveu. Referring to their papers of 1894 and 1898, they say, "Jusque dans ces derniers temps on n'avait cité que des cas très douteux de trypanosomes chez l'homme." 19 We have consulted with Dr. Laveran on the subject, and he authorises us to say that he sees no reason for changing this opinion of the papers of Dr. Barron and Dr. Nepveu.

Mr. R. M. Forde and Dr. J. S. Dutton (1901). -This case need not detain us long. The first publication was by Dr. J. S. Dutton. ${ }^{20}$ He states that the case in which the parasites were found was admitted into hospital at Bathurst, Gambia, with fever on May 10th, 1901, under the care of the colonial surgeon, Mr. R. M. Forde. The patient's blood was examined by Mr. Forde ; and Dr. Dutton says : "Mr. Forde informed me that he saw very many actively moving wormlike bodies whose nature he was unable to ascertain." The patient was now invalided to England and on August 12th entered the Royal Southern Hospital, Liverpool, where he suffered from "three short periods of pyrexia" and other symptoms. Here Dr. Dutton examined his blood for malarial parasites on two occasions, with negative results, and Dr. C. J. Macalister recorded his case. In December the patient arrived in the Gambia again and Mr. Forde asked Dr. Dutton (who also had arrived in the Gambia on a scientific mission) to examine his blood once more. Dr. Dutton expressly admits (p. 455) that this request was made "on account of "Mr. Forde's previous observation of the " actively moving worm-like bodies whose nature he (Mr. Forde) was unable to ascertain." On doing so (Dec. 15th) Dr. Dutton, who had previously found nothing in the

19 Laveran and Mesnil : Des Maladies à Trvpanosomes, leur Répartition à la Surface du Globe, Janus, Mars 15. $190 \%$.

20 Dutton: Preliminary Note upon a Trypanosome occurring in the Blood of Man, Thompson-Yates Laboratory Reports, May, 1902. patient's blood, now succeeded in detecting nnquestionable trypanosomes to the number of only three in three slides.

Such is the history of the discovery as taken from this paper. The rest of the paper gives a close analysis of the symptoms of the case as observed by Mr. Forde, Dr. Macalister, and Dr. Dutton; and a detailed description of the parasites, including their form, movement, numbers, size, and staining reactions, as observed by Dr. Dutton during a long study of the subject. $\mathrm{He}$ gives also a coloured drawing of the stained parasite and photographs of it and of allied organisms in animals (T. Lerisi, Brucei, and equiperdum); and compares the human parasite, which he names " T. gambiense," with these, and also the symptoms produced by it in man with those produced by them in animals. The previous claim of Dr. Nepveu is briefly considered. Charts comparing the temperature in man and in nagana are added. In a footnote at the conclusion of the paper Dr. Dutton states that "since going to press" he has found the same parasites in one out of 115 dried blood films taken from native children in the Gambia during his visit there.

We should add that shortly after the discovery was made both Dr. Dutton and the patient returned to England. Here Dr. Dutton, Dr. H. E. Annett, and Mr. J. L. Todd continued the study of the case, both of the parasites and of the symptoms. The parasites were exhibited at the Royal Society, and at Liverpool in connexion with the annual meeting of the British Medical Association; and both the case and the parasites were shown to many others, including ourselves. Dr. Dutton contributed another paper on the subject to the British Medical Association, July 29th, 1902. ${ }^{21}$ This is practically a repetition of the former paper, except that the consideration of Dr. Nepveu's claim is omitted.

Meantime Mr. Forde, who had first seen the parasites in May, 1901, seems to have published nothing on the subject On Sept. 1st, 1902, however, a paper from his pen ${ }^{22}$ appeared giving some of the clinical details of the case during the periods when the patient was under his care in 1901. He substantiates Dr. Dutton's account of the discovery, but adds that when he (Mr. Forde) first saw the parasites he "prematurely pronounced" them to be "a species of filaria" that this conclusion "became doubtful after repeated observa tions of the parasite"; that he showed the case to Dr. Dutton ; and that Dr. Dutton "at once recognised" "the parasite" "as a species of trypanosoma." Mr. Forde adds that it was also Dr. Dutton who recognised the peculiar undulant nature of the fever.

The leading facts appear to be clear and undisputed. Later, however, Mr. Forde ${ }^{23}$ published a letter in which he seems to claim having made the discovery by himself in May, 1901, when he first saw the parasites. This view may be contested, as we have his own words to the effect that he then thought the parasites were a species of filaria and that it was Dr. Dutton who recognised them to be a species of trypanosoma. We may note, also, that he published nothing on the subject (so far as we know) until 15 months after his first observation, and three months after Dr. Dutton's first publication. On the other hand, it was undoubtedly $\mathrm{Mr}$. Forde who drew Dr. Dutton's attention to the existence of parasites in the case. In the circumstances we think that most people will consent to the opinion that the names of Mr. Forde and Dr. Dutton ought to be associated in the history of the discovery. Dr. Macalister also contributed some clinical details. Whatever the claims of others may be it was certainly Dr. Dutton who first established the existence of trypanosomes in human beings in a manner fully satisfactory to science, and it was also he who was the first to give adequate descriptions and illustrations of the new parasite and a comparison of the symptoms with those of other forms of trypanosomatosis in animals. The case of Mr. Forde and Dr. Dutton has been so thoroughly investigated, especially by the latter, and is so well attested, that it is unnecessary to examine the confirmations of the discovery which have already been made public-namely, a case of Dr. Habershon, Dr. Manson, and Mr. Daniels, and some fresh cases of Dr. Dutton and Dr. Todd..$^{24}$

21 Dutton : Note on a Trypanosoma occurring in the Blood of Nan, Brit. Med. Jour., 1902, vol. ii.. p. 881 .

22 Forde: Some Clinical Notes on a European Patient in whose Blood a Trypanosoma was observed, Journal of Tropical Medicine, Sept. 1st. 1902

23 Forde: The Discovery of the Human Trypanosoma, Brit. Med. Jour., Nov. 29th, 1902.

24 Editorial in the Brit. Med. Journ., 1902, vol. ii., p. 1452, describing a case of Dr. Habershon. Dr. Manson, and Mr. Daniels. Dutton and Todd : Brit. Med. Jour., Feb. 7th, 1903. 
We may, perhaps, be justified in concluding this discussion by some words of Charles Darwin. ${ }^{25}$ "I I feel sure," he writes to a correspondent, "as long as species-mongers have their vanity tickled by seeing their own names appended to a species, because they miserably described it in two or three lines, we shall have the same vast amount of bad work as at present and which is enough to dishearten any man who is willing to work out any branch with care and time." In order to obtain the credit for an observation much more is necessary than just to record once in print that it has been made, without taking any trouble to convince others, without publishing accurate descriptions or drawings, or even without giving a full account of the circumstances under which the observation was made. Of course, science cannot accept this sort of thing; to do so would be to admit every kind of pretender. For instance, anyone can record a statement to the effect that he has seen a new parasite, and can even furnish a good general description of it drawn from descriptions of allied parasites found in other hosts and given in the text-books. That such a thing is done with intent to deceive is happily not very likely; but unfortunately it can often be done unconsciously by inexperienced students (especially in connexion with minute parasites of the blood), who having found some object which seems to them to accord with the text-book description, rush into print, full of ardour for their new discovery. A timely remembrance of the words of Darwin would not only save many such from the disappointment of finding their claims rejected, but would also guard the interests of "the man who is willing to work out any branch with care and time."

\section{ON THE PERMANENT CARE OF THE FEEBLE-MINDED. ${ }^{1}$}

BY MRS. ELLEN F. PINSENT,

CHATRMAT OF THE AFTER-CARE COMMTTTEE OF THE BIRMTNGHAM SCHOOL BOARD.

I HAVE some hesitation in speaking of the value of the work of an after-care committee when the only one of which I know anything bas been in existence so short a time, but I may succeed in giving some idea of the difficulties with which it is necessary to contend. The first important question is as to the advisability of establishing such committees. On this point I have no hesitation. I am most anxious to see them established wherever there are classes for the mentally deficient. I think that all those who have had anything to do with these children are agreed that there is no stated age when they can be considered grown up or treated as responsible adults. Many, I believe most, are as much children at 16 pears of age as they were at 10 ; the only difference being that, as at 16 they are capable of doing greater harm, they therefore require greater care when they reach that more dangerous age. I do not think it possible that much lasting help can be given by members of after-care committees in the majority of cases, and yet the children in these very cases are just those who are absolutely unfit to face the world without permanent care.

When we started an after-care committee in Birmingham our immediate aim was to find situations for those children who left the special classes capable of work, and also to see if there was anything that could be done for the hopeless cases where the children were found to be incapable of work. This, I say, was the immediate object but it was by no means the most important in the minds of those who formed the committee. It was established first and foremost as an inves tigation committee with the object of estimating the worth of the laborious and expensive education given in special classes. It was hoped that if for some years after they left school the careers of these unfortunate children were closely watched and accurately reported the committee would then have some facts to place before educationalists which would enable them to judge how far the special class really meets the requirements of mentally deficient children. We hope too, to be able to show how many of those who leare special

25 F. Darwin : Charles Darwin, p. 159. London : John Murray, 1902. 1 A paper read before a Conference held at Leicester on Nov. 26th, 1902, upon the Treatment of the Mentally Defective. classes ultimately become self-supporting or even partially self-supporting. It is too early in our history to place any great confidence in our figures, but such as they are I will give them to you.

We had 48 children on our list to begin with and of these we found it impossible to trace 13. This, I hope, is a larger percentage than will ever occur again. Many of these children had left school for some years before we began work. Now that each case is taken up at once and constantly watched we shall have a better chance of tracing them, though I am afraid we shall always lose a certain number. The parents are perpetually flitting, and as there are so few after-care committees, when a child goes to another town we have no organisation to whom to hand him or her over. We feel this a good deal in Birmingham; for, although our children may only go a short distance-to Smethwick, Aston, Handsworth, or Yardley, which are all in reality part of one great population-yet these children are often com. pletely lost, as none of these places have even special classes, much less after-care committees. Thus, some years work in a special class may be rendered almost useless from the fact that the child's parents have moved out of our school board district.

Before passing on I should like to point out that the children who are perpetually wandering are almost always the offspring of low and degraded parents and probably if they were found would swell the numbers of the incapable and hopeless. This should not be forgotten when conclusions are drawn from our statistics. It also points to the advisability of such children being placed in a boarding school where they could be kept under permanent control and not left to the chance of their parents remaining in the neighbourhood of a special class or of an after-care committee. There can be no doubt that many parents of feebleminded children, belonging as they so often do to the streethawker and irregularly employed class, are even more migratory than the rest of town populations. This is one of our most disheartening difficulties; for, unless the aftercare association can establish permanent custodial homes it must always lose a large percentage of cases, and every lost case may mean, and generally does mean, a future generation of feeble-minded children.

of the 35 remaining persons 16 are at work. The average age of these 16 persons is 17 years, and the average weekly wage which they earn is 5s. 9d. - one boy earns $10 s$. a week. We have not at present been established long enough to know how often these persons change their situations, or the amount of time wasted during such changes, which if considerable would, of course, lower their weekly wage. But speaking generally, I believe that our investigations will show that they are perpetually changing their situations. Certainly of the four cases which have come under my own eye only one is satisfactory; one person is too bad to work at all ; one never keeps his situation more than a few weeks and the other never more than a few months. Neither of the latter will ever be capable of self-support after their near relations die and I think it probable that both will find their way into gaol. Here they will cost at least as much as in an industrial colony where I feel sure that working under supervision both could have contributed largely to their own support. These cases I believe to be typical of most of the 16. A small percentage will get along passably, but by far the greater number will eventually be found in the prison, the penitentiary, or the workhouse. The next seven children on our list, although capable of work, are out of work. This you will notice is nearly one-third of the total number of cases in which the subjects are capable of work. Our aftercare committee will probably get them work of some kind, but by that time others will have lost their situations and fancy our books will show that this is about the usual proportion. Our utmost efforts will probably prove inadequate, there will always remain a third doing nothing. If those who fail to keep their situations were placed in industrial colonies they would work continously with greater profit both to themselves and to society at large.

I have now accounted for 23 out of our 35 children. Of the remaining 12 one has died, five are so bad that they should be placed at once in some asylum or home, and six are being looked after fairly well at home but are incapable of work and will have to be provided for on the death of the mother. I have said fairly well looked after and by this I mean that they are clothed, fed, and kept passably clean, but I do not believe for a minute that they are protected from all chance of moral harm. Some of them are girls who should never be 